\title{
Közbeszerzés lebonyolítása a hatályos jogszabályok tükrében
}

\section{Liquidation of public procurement due to operative regulations}

\author{
É. DIÓSZEGINÉ ZENTAY \\ Debreceni Egyetem Műszaki Kar,zentayevi@eng.unideb.hu
}

\begin{abstract}
Abszrakt: A Közbeszerzésekről szóló új törvény célja, hogy biztosítsa a közpénzek hatékonyabb felhasználását. Az új szabályozás eredményeképpen jelentôsen meggyorsulnak a közbeszerzési eljárások, növekszik az átláthatóság és a verseny. Továbbra sem lesz egységes az uniós értékhatár alatti eljárások rendje, mivel a törvény a becsült érték alapján differenciálja a szabályokat. Fontos változás az értékelés kapcsán, hogy a kizárólag ár alapú rangsorolás helyett az ár-érték módszer alkalmazása kerül előtérbe.
\end{abstract}

Abstract: The aim of new Public Procurement law is to ensure the efficiency of appropriation public money. On new lwgal regulation public procurement procedure sbecome significantly faster and transparency and competition are increasing. Hence forward the rules of procedures under Europian Union limit won't be standard. Innationalprocurementprocedurestherulesaredifferentiatedfromestimatevalue. Important change in connection with valuation base dont he lowest price is succeeded by the method of proportion price and value.

\section{Bevezetés}

A Magyar Közlöny 142. számában került kihirdetésre a közbeszerzésekről szóló 2015. évi CXLIII. Törvény. Az új jogszabály jelentős módosításokat tartalmaz a közbeszerzési eljárások lefolytatásában, a változások többsége november elsején hatályba is lépett. A norma teljesen új alapokra helyezi a közbeszerzés szabályait, így a becsült érték fogalom és az egybeszámítás, a felelős akkreditált közbeszerzési tanácsadó bevonása mind újdonságot jelentenek a jogalkalmazók és joggyakorlatot folytatók számára. Az új törvény megalkotásával párhuzamosan elkészültek a kapcsolódó rendeletek is, melyek sajátos közbeszerzési szabályokat tartalmaznak a közszolgáltatók, a központi ellenőrzés és engedélyezés vonatkozásában. Szintén külön kormányrendelet szabályozza a tervpályázati eljárásokat és az építési beruházásokat. A 44/2015 MvMrendelet a nemzeti eljárásrend során alkalmazandó nyomtatvány mintákat tartalmazza, míg az uniós eljárásrend mintáit a 2015/1986 végrehajtási rendelet szabályozza. A jogszabályalkotás visszásságát mutatja, hogy utóbbi minták csak idén februártól lettek elérhetőek, így egészen 2016. április 16-ig a régi mintákat kell alkalmazni, melyek viszont nincsenek mindig összhangban az új törvénnyel, valamintmártöbbszörhajtottakvégrekisebbnagyobbmódosításokatazújKbt-ben. Megfigyelhető, hogy az új szabályozás hatályba lépését 
megelőzően a gazdasági szereplők igyekeztek minél több eljárást elindítani, ígyazújtörvényalapjánlefolytatotteljárásokésjogorvoslatoktekintetébenmégkevéstapasztalattalrendelk ezik a piac.

\section{Változások a közbeszerzés szabályozásában}

A közbeszerzési jogszabályok 1995. óta képezik a magyar gazdasági jog részét, melyek ma már hivatali, közigazgatási és az ezekkel kapcsolatba kerülő szervek és gazdálkodók mindennapi munkájának részévé váltak. A jelenleg hatályos jogszabály célja biztosítani az Európai Unió közbeszerzési irányelveivel való összhangot, mely egyben a jogharmonizációs kötelezettség maradéktalan teljesítését is jelenti. A jogalkotó figyelembe vette a jogalkalmazásban felmerült tapasztalatokat, illetve fontos cél volt a közpénzfelhasználás átláthatóságának, nyilvánosságának erősítése, és ezen keresztül az állami pénzekkel való visszaélés, a korrupt magatartások visszaszorítása és megelőzése.

A törvény hatálybalépése több lépcsőben zajlik, melynek eredménye az elektronikus közbeszerzési rendszer teljes kialakítása.

\section{1.Újtörvény - újlogika}

Az új jogszabály nyolc részre tagolódik, alapvetően új tartalmi elemet a Negyedik rész jelenti, mely a Koncessziós beszerzési eljárásokat szabályozza. A törvény felépítése:

- Első rész: Általános rendelkezések

- Második rész: Az uniós értékhatár feletti közbeszerzések szabályai

- Harmadik Rész: Az uniós értékhatár alatti beszerzések szabályai

- Negyedik rész: Koncessziós beszerzési eljárás

- Ötödik rész: A szerződésekkel kapcsolatos szabályok

- Hatodik rész: A jogorvoslat

- Hetedik rész: A Közbeszerzési Hatóság

- Nyolcadik rész: Záró rendelkezések.

Annak meghatározására, hogy kell-e közbeszerzést lefolytatni a gazdasági szereplőnek és milyen eljárásrendet kell alkalmaznia, a következő szempontokat kell figyelembe venni:

a) alanyi hatály

- Klasszikus Ajánlatkérők

- Közszolgáltatók

b) tárgyi hatály

- Árubeszerzés

- Építési beruházás

- Építési koncesszió

- Szolgáltatás megrendelése

- Szolgáltatási koncesszió 
A törvény 9. - 14. §-ai azokat a kivételeket tartalmazzák, melyek esetében a törvényt nem kell alkalmazni.

c) értékhatárok

- Az uniós értékhatárokat az Európai Bizottság állapítja meg és teszi közzé.

- Nemzeti értékhatárokat a költségvetésről szóló törvényben határozzák meg.

- Közbeszerzési Hatóság honlapján teszik közzé.

\begin{tabular}{|l|l|l|l|l|}
\hline $\begin{array}{l}\text { Közbeszerzés } \\
\text { tárgya }\end{array}$ & $\begin{array}{l}\text { Nemzeti } \\
\text { Klasszikus }\end{array}$ & \multicolumn{1}{|c|}{$\begin{array}{l}\text { Körtékhatár } \\
\text { Közösségi }\end{array}$} & \multicolumn{2}{l|}{$\begin{array}{l}\text { Értékhatár } \\
\text { Klasszikus }\end{array}$} \\
\hline $\begin{array}{l}\text { Árubeszerzés, } \\
\text { szolgáltatás } \\
\text { megrendelése }\end{array}$ & 8 millió Ft & 50 millió Ft & $\begin{array}{l}41427450 \mathrm{Ft} \\
64135830 \mathrm{Ft}\end{array}$ & $128271660 \mathrm{Ft}$ \\
\hline $\begin{array}{l}230152500 \mathrm{Ft} \\
\text { Építési beruházás }\end{array}$ & 15 millió Ft & 100 millió Ft & $1603395750 \mathrm{Ft}$ & $1603395750 \mathrm{Ft}$ \\
\hline Építési koncesszió & 100 millió Ft & 200 millió Ft & $1603395750 \mathrm{Ft}$ & \\
\hline $\begin{array}{l}\text { Szolgáltatási } \\
\text { koncesszió }\end{array}$ & 25 millió Ft & 100 millió Ft & $1603395750 \mathrm{Ft}$ & \\
\hline
\end{tabular}

1. táblázat: Közbeszerzési értékhatárok Saját szerkesztés

(Forrás: 2015/C 392/01 számú közlemény)

\subsection{Becsültértékmeghatározása}

Újdonságként jelenik meg, hogy „közbeszerzési eljárás becsült értéke” alatt már a közbeszerzés megkezdésekor annak tárgyáért az adott piacon általában kért vagy kínált - áfa nélkül számított teljes ellenszolgáltatást kell érteni, így életszerűbb helyzetet teremt a 2011. évi CVIII. törvény által rögzített legmagasabb összegű ellenszolgáltatás fogalmával szemben.

Az opcionális rész tekintetében változatlan marad a jogszabály, hiszen a teljes ellenszolgáltatásba az opcionális rész értékét is bele kell érteni, mindezt ugyanúgy, ahogy az ajánlatkérő által a részvételre jelentkezők vagy az ajánlattevők részére fizetendő díjat vagy egyéb kifizetést (jutalékot) is (amennyiben az ajánlatkérő teljesít ilyen jellegű fizetést). A részekre történő ajánlattétel esetén a közbeszerzés becsült értékébe minden rész értékét továbbra is majd egybe kell számítani.

Az Európai Parlament és a Tanács 2014/24/EU irányelve egyértelműen rögzíti a becsült érték időbeliségét. Eszerint a becsült érték abban az időpontban érvényes, amikor az eljárást megindító felhívást elküldték, illetve - azokban az esetekben, amikor ilyen felhívásra nem kerül sor - abban az időpontban, amikor az ajánlatkérő szerv megindítja a közbeszerzési eljárást. Az új közbeszerzési törvény értelmező rendelkezése alapján ilyen lehet az, amikor az ajánlatkérő a hirdetményt megküldi a Közbeszerzési Hatóságnak vagy a felhívást az ajánlattételre felkért gazdasági szereplőknek küldi ki. 
Ami azonban mindenképpen jelentős változás a korábbi szabályozáshoz képest az a kivételként deklarált eset, amikor az ajánlatkérő szervezet több különálló működési vagy szervezeti egységből áll, és ezen különálló múködési egység saját gazdasági szervezettel rendelkezik és működési költségvetése felett önálló rendelkezési joggal bír. Ilyen esetben ugyanis az elfogadott jogszabályi szövegbe egy „is” szó került rögzítésre, amellyel az ajánlatkérőnek választási lehetőséget biztosítanak arra, hogy a különálló működési egység szintjén vagy a teljes ajánlatkérő mint egész szintjén határozza meg a tényleges becsült értéket.

További új eleme az eddigi szabályozásnak az a következő rendelkezés, amit az eljárás előkészítő szakaszában az ajánlatkérők részére kötelező erővel előír. Eddig ajánlatkérőknek ugyanis nem volt jogszabályi kötelezettsége dokumentálni a becsült érték meghatározásának a módszerét, így előfordult, hogy a becsült érték nem volt a tényleges valós helyzetnek megfelelő, így előzetes vitarendezésre és jogorvoslati eljárásra is kellő alapot szolgáltathatott. Az új szabályozás ezt a vitás helyzetet kívánta orvosolni azzal, hogy ajánlatkérői törvényi kötelezettség formájában írta elő a becsült érték vizsgálatát, továbbá a vizsgálat eredménynek a dokumentálását is. Ilyen objektív módszerek lehetnek különösen: beszerzés tárgyára vonatkozó indikatív ajánlatok bekérése, a beszerzés tárgyára vonatkozó, arra szakosodott szervezetek által végzett piackutatás, igazságügyi szakértő igénybevétele és a szakmai kamarák által ajánlott díjszabások, valamint a szakmai kamarák által előállított és karbantartott, megvalósítási értéken alapuló részletes építési adatbázis, továbbá a Közbeszerzési Hatóság által kiadott árstatisztika, valamint az ajánlatkérő korábbi, hasonló tárgyra irányuló szerződéseinek elemzése is.

A jogalkotó külön címként kiemeli az ún. vegyes beszerzések fogalmát, mely azonban a korábbi jogszabályban is megtalálható volt. A vegyes beszerzések lényege, hogyha a közbeszerzés többféle beszerzési tárgyat foglal magában, a közbeszerzési eljárásra a beszerzésfötárgyaszerintiszabályokatkellalkalmazniaazajánlatkérőnek.

\subsection{Egybeszámításszabályai}

Az egybeszámítás szabályai között változatlan maradt az az eset, amikor az ajánlatkérőnek építési beruházás vagy ugyanazon közvetlen cél megvalósítására irányuló szolgáltatás megrendelése áll fenn, illetve, ha azonos vagy hasonló felhasználásra szánt áruk beszerzése részekre bontva, több szerződés útján valósul meg, ilyenkor a közbeszerzés becsült értékének meghatározásához továbbra is az összes rész értékét figyelembe kell venni. Azonban, amennyiben az előbb említett szabályozás alapján a közbeszerzés megállapított becsült értéke eléri vagy meghaladja az uniós értékhatárokat, úgy az ajánlatkérőnek lehetősége van továbbra is az uniós eljárásrend helyett a nemzeti eljárásrend szerint lefolytatni a közbeszerzési eljárását.

A részekre bontás tilalma tekintetében azonban figyelemmel kell lenni az Irányelvre is, mely szerint: amennyiben az ajánlatkérő szerv úgy határoz, hogy nem volna célszerű a közbeszerzést részekre bontani, egyedi jelentésében vagy a közbeszerzési dokumentumaiban meg kell jelölni döntésének főbb okait. Ilyen ok lehet például, ha az ajánlatkérő szerv úgy ítéli meg, hogy a részekre osztás a verseny korlátozásával járhat, vagy fennáll annak a kockázata, hogy a szerződés teljesítése technikailag 
túlságosan bonyolult vagy túlságosan drága lesz, vagy az egyes részeket elnyerő különböző szerződő felek szükséges koordinálása súlyosan veszélyeztetheti a szerződés megfelelő teljesítését.

Az új jogszabály indokolásából egyértelműen megállapítható, hogy nem kell összevonni a becsült érték meghatározása szempontjából a különböző építési beruházáshoz vagy támogatáspolitikai értelemben vett projektekhez kapcsolódó azonos vagy a hasonló szolgáltatás megrendeléseket sem. Továbbá az ugyanazon épületre vonatkozó engedélyezési tervdokumentáció elkészítésének értékét az esetleges kivitelezési tervdokumentáció értékével össze kell vonni, adott esetben még akkor is, ha azok különböző projektekhez kapcsolódnak.

Az elfogadott új törvény az árubeszerzés esetét a 2011. évi CVIII. törvényhez képest pontosítja, mely szerint az „azonos” áruk beszerzésének értékét összevontan kell kezelni, mint ahogy a „hasonló felhasználásra szánt áruk" esetét is.

Az építési beruházás becsült értékébe be kell számítani a megvalósításához szükséges, az ajánlatkérő által rendelkezésre bocsátott áruk és szolgáltatások becsült értékét is. Itt kiemelendő, hogy a 2011.évi CVIII. törvény általi megfogalmazás pontosításra került, hiszen az építési beruházás becsült értékének megállapításaként a teljes - műszaki és gazdasági szempontból funkcionális egységet képező - építési beruházásért járó ellenértéket kell figyelembe venni. (5)

\subsection{Gyorsabbközbeszerzés}

Több eljárási határidő is csökken, amely jelentősen gyorsítja a közbeszerzési eljárásokat. Így pl. az uniós eljárásrendben a 45 napos minimális ajánlattételi határidő 35 napra mérséklődik, elektronikus benyújtás esetén 30 napra. Ettől eltérően legalább 5 nappal hosszabb határidőt kell hagyni, ha az ajánlatkérő egyes dokumentumok esetén nem biztosítja a közvetlen elektronikus hozzáférést. Kivételesen, sürgősség esetén pedig lehetőség lesz gyorsított nyílt eljárást is alkalmazni, 15 napos ajánlattételi határidővel. Nemzeti eljárásrendben a minimális ajánlattételi határidő - árubeszerzés és szolgáltatás-megrendelés esetén - 10 nap, míg építési beruházásnál 15 nap, azonbanazegyszerűsítettszabályokkallefolytatotteljárásbanmégezeksemkötelezők.

\subsection{Vátozásazértékelésvonatkozásában}

Ajánlatkérő a legelőnyösebb ajánlat kiválasztására három módszer közül választhat:

- a legalacsonyabb ár,

- a legalacsonyabb költség, amelyet az ajánlatkérő által meghatározott költséghatékonysági módszer alkalmazásával kell kiszámítani, vagy

- a legjobb ár-érték arányt megjelenítő olyan - különösen minőségi, környezetvédelmi, szociális szempontok, amelyek között az ár vagy költség is szerepel. (1)

Az ajánlatkérő csak akkor választhatja a legalacsonyabb ár egyedüli értékelési szempontját, ha az ajánlatkérő igényeinek valamely konkrétan meghatározott minőségi és műszaki követelményeknek megfelelő áru vagy szolgáltatás felel meg, és a gazdaságilag legelőnyösebb ajánlat kiválasztását az adott esetben további minőségi jellemzők nem, csak a legalacsonyabb ár értékelése szolgálja. Az 
ajánlatkérő nem alkalmazhatja a legalacsonyabb ár szempontját egyedüli értékelési szempontként tervezési, mérnöki és építészeti szolgáltatások, valamint építési beruházások esetében.

\subsection{Felelősakkreditáltközbeszerzésitanácsadó}

Látszólag teljesen új fogalmi elemként jelenik meg az ún.felelős akkreditált közbeszerzési szaktanácsadó, mely lényegében a hivatalos közbeszerzési tanácsadó jogutódja. Ami viszont új tétel, hogy részben vagy egészben európai uniós forrásból megvalósuló, valamint árubeszerzés és szolgáltatás megrendelése esetén az uniós értékhatárt meghaladó, építési beruházás esetén az 500 MFt-ot meghaladó értékű közbeszerzési eljárásba kötelező a szaktanácsadó bevonása. A Közbeszerzési Döntőbizottság előtti jogorvoslati eljárásban is kötelező lesz vagy felelős akkreditált közbeszerzési szaktanácsadó, vagy ügyvéd, avagy jogtanácsos igénybevétele.

\subsection{Módosítások a nemzeti eljárásrendben}

Továbbra sem lesz egységes az uniós értékhatár alatti eljárások rendje, mivel a törvény a becsült érték alapján differenciálja a szabályokat.

Fő szabály szerint nemzeti eljárásrendben az ajánlatkérő az eljárást megindító felhívását nem teszi közzé hirdetményként a Közbeszerzési Értesítőben, hanem egy összefoglaló tájékoztatást jelentet meg a Közbeszerzési Hatóság honlapján, legalább 5 nappal az eljárás megindítása előtt. Ezt követően az ajánlatkérő nemcsak az általa kiválasztott minimum három gazdasági szereplőnek köteles megküldeni a felhívását, hanem azoknak is, akik a tájékoztató alapján jelezték érdeklődésüket az eljárás iránt. Ez a „könnyítés” csak az uniós értékhatár alatti árubeszerzés és szolgáltatás-megrendelés, valamint építési beruházás esetén alkalmazható.

Lehetőséget ad a törvény szabadon kialakított eljárásrend lefolytatására a 117. § alapján. A kógencia alkalmazásával ajánlatkérő maga írhatja az eljárás szabályait.

A nemzeti eljárásrendben belül egyszerűsített szabálya 18 MFt alatti árubeszerzésekre és szolgáltatásmegrendelésekre, valamint 100 MFt alatti építési beruházásokra. Ezekre „tényleges” hirdetmény nélküli eljárás folytatható, amikor nem lesz kötelező az előzetes tájékoztató megjelentetése sem, viszont az új szabályok szerint:

„Az ajánlatkérő köteles legalább három gazdasági szereplőnek megküldeni az eljárást megindító felhívást, valamint mindazoknak a gazdasági szereplőknek is, akik az ajánlatkérőnél az eljárás iránt érdeklődésüket jelezték. Ha az eljárás iránt háromnál kevesebb gazdasági szereplő jelezte érdeklődését vagy egyetlen gazdasági szereplő sem jelezte érdeklődését, abban az esetben is legalább három gazdasági szereplőnek kell felhívást küldeni."

Fontosnak tartom megemlíteni, hogy a Miniszterelnöki Hivatal és a Hatóság vitázik azon, hogy a 3 kiválasztott ajánlattevőt hogy kell értelmezni. Jelen állás szerint a Hivatal azt mondja, hogy az érdeklődést kifejező gazdasági szereplőn túl további hármat kell felkérni, míg a törvényalkotó úgy magyarázza, hogy összesen legalább három gazdasági szereplő legyen. 
Az új Kbt. módosítja a szolgáltatások felosztását, és változnak a szabályok is a „kedvezményezett szolgáltatásokra". Egyrészt ezekre a szociális és egyes speciális szolgáltatásokra akkor is nemzeti eljárást kell lefolytatni, ha a becsült érték egyébként az uniós értékhatárt is meghaladja. Másrészt, ha ezen szolgáltatás becsült értéke nem éri el a 18 MFt-ot, akkor egyáltalán nem kell eljárást lefolytatni, mivel a Kbt. ezt a kivételi körbe sorolja és így ajánlatkérő mentesül a közbeszerzési kötelezettség alól.

\subsection{Kutatásieredményazelmúlt hat évközbeszerzéseiről}

A Korrupciókutató Központ kutatói (CRCB) nemrégiben több mint 125 ezer közbeszerzés anyagát nézték át 2009-2015 időszakából, amelyből kiderült, hogy akár 130-320 százalék közötti túlárazás is előfordulhat.

A kutatás 5 fő üzenete a következő:

1. Csökken a verseny a közbeszerzéseknél

2. Folyamatosan növekednek a korrupciós kockázatok

3. Növekszik a túlárazás mértéke és gyakorisága is

4. Az ártorzítás borzasztóan magas, becsült értéke 130-320 százalék

5. Az EU-s támogatásoknak visszás hatása van: csökkentik a versenytésnövelik a korrupciót .(6)

A közbeszerzések kapcsán tehát általános tendencia, hogy a verseny fokozatosan csökken, miközben a transzparencia is egyre alacsonyabb szinten van. A túlárazás megakadályozása érdekében a jogszabály lehetővé teszi, hogy az ajánlatkérő előre meghatározzon egy összeget, amelyek fölött érvénytelenné nyilvánítja az ajánlatot. Az új jogszabályok megalkotásával remélhetőleg javulni fog a verseny tisztasága a közbeszerzések terén, illetve a közpénzek felhasználásának hatékonysága. Aggodalomra ad okot véleményem szerint, hogy a kormány igyekszik a 2020-ig tartó ciklustámogatásait lehívni, melysoránazépítőiparbankeretmegállapodásokmegkötésévelkorlátozza a versenyt. A 321/2015 kormányrendelet szabályozása alapján pénzügyi és gazdasági alkalmasság igazolása kérhető (legalább egy műszaki-szakmai és egy pénzügyi alkalmasságot elő kell írni ajánlatkérőnek), melynél olyan referencia került meghatározásra, amivel csak korlátozott számú piaci szereplő rendelkezik. (3)

\section{Összegzés}

Az új jogszabály több ponton is módosítja a korábbi szabályokat. A legfontosabb változás az értékelési szempontokat érinti. Nem a legolcsóbb ajánlatok kapják a legmagasabb pontszámot. Ehelyett előtérbe helyezik a munkahelyteremtést, az innovatív megoldások alkalmazását, a gazdaságfejlesztés szempontjait, minőségi alapokra helyezik a kiválasztást. Mindez azt jelenti, hogy hiába adja egy cég a legolcsóbb ajánlatokat, nem lehet biztos a sikerében.

Nyílt eljárásban az ajánlatkérő rendelkezhet úgy, hogy az ajánlati ár vizsgálatát csak az ajánlatok formai és tartalmi értékelését követően, és kizárólag a legkedvezőbb ajánlatot tevő (és adott esetben a második helyezett) tekintetében végzi el. Amennyiben ezen ajánlat emiatt érvénytelennek minősül, akkor szükséges csak elvégezni az ár vizsgálatát a sorban következő ajánlattevő esetén. 
Ajánlatkérő köteles a közbeszerzési dokumentációt (ajánlati dokumentációt és annak mellékleteit) elektronikus úton térítésmenetesen hozzáférhetővé tenni, ezekért a nyertes ajánlattevőtől sem lehet ellenértéket kérni. Amennyiben bizonyos dokumentumok elektronikus kiadása bármely okból nem teljesíthető, akkor a hozzáférés módjáról külön kell rendelkezni.

Bővülnek az összeférhetetlenségi szabályok, így a jövőben sem ajánlattevőként, sem alvállalkozóként nem vehetnek részt közbeszerzési eljárásban a Kbt-ben nevesített állami vezetők és hozzátartozóik (ha egy háztartásban élnek) tulajdonában álló szervezetek, a nyilvános részvénytársaságok kivételével.

\section{Hivatkozások}

[1] 2015. évi CXLIII. Törvény a közbeszerzésekről

[2] 2011. évi CVIII. Törvény a közbeszerzésekről

[3] 2015/C 392/01 számú közlemény

[4] 321/2015 kormányrendelet a közbeszerzési eljárásokban az alkalmasság és a kizáró okok igazolásának, valamint a műszaki leírás meghatározásának módjáról

[5] 322/2015 kormányrendelet az építési beruházások, valamint az építési beruházásokhoz kapcsolódó tervezői és mérnöki szolgáltatások közbeszerzésének részletes szabályairól

[6] Stregth of competition and corruption risks. Statistical analysis of hungarian public procurement - 2009-2015. Data and descriptive statisticspublications, reports, march 3 2016

[7] 46/2015 MvM rendelet a felelős akkreditált közbeszerzési szaktanácsadók előzetes regisztrációjáról 